\title{
Yam Breeding in Ghana
}

\author{
Emmanuel Otoo ${ }^{1}$ \\ ${ }^{1}$ CSIR-Crops Research Institute, Kumasi, Ghana \\ Correspondence: Emmanuel Otoo, CSIR-Crops Research Institute, P.O. Box 3785, Kumasi, Ghana. E-mail: \\ otooemmanuel@gmail.com
}

Received: June 3, 2017

Accepted: August 2, $2017 \quad$ Online Published: September 15, 2017

doi:10.5539/jas.v9n10p122

URL: https://doi.org/10.5539/jas.v9n10p122

\begin{abstract}
CSIR-Crops Research Institute of Ghana is the National Centre of Specialization (NCOs) for Root and Tuber Crops and migrating into a Regional Centre of Excellence (RCOE) in Root and Tuber research in the West African sub-region. Yam is one of the major root and tuber crops of importance in the sub-region and for that matter the NCOS. Even though yams are indigenous to the West African sub-region, with the exception of Dioscorea alata (Asiatic origin), yams are often aptly described as an orphan crop due to the relatively little research effort compared to its significance in the sub-region in particular and the world at large. Breeding of yams therefore can be a challenge due to little literature available on the subject matter. This paper looks at the historic perspective, what can be done presently and projects into future direction of yam breeding in Ghana and the world at large. It also serves as a guide for yam breeding in particular and root and tuber crops in general.
\end{abstract}

Keywords: breeding, Ghana, Dioscorea, yams

\section{Introduction}

Yams are grown in tropical and subtropical Africa, Central and South America, parts of Asia, and the Caribbean and South Pacific Islands (Coursey, 1967; Adelusi \& Lawanson, 1987). There are over 600 species of yam within the family, Dioscoreaceae, of which nine are medicinal plants and eight species, namely D. rotundata (white yam), D. bulbifera (air-potato yam), D. cayenensis (yellow Guinea yam), D. dumentorum (bitter or trifoliate yam), D. praehensilis (kokoasebayere), D. esculenta (lesser yam), D. trifida (cush-cush yam) and D. alata (greater or water yam) are edible. In the West African sub-region where $97 \%$ of world yam is produced, $D$. rotundata, $D$. cayenensis, D. alata, D. dumentorum, D. praehensilis, and D. bulbifera are the species of importance in that order.

Crop improvement or plant breeding is an applied branch of botany that deals with the improvement of crops and production of new crop varieties, which are far superior to existing types in one or more characters. Plant breeding therefore has been defined as science, art and technology of changing the traits of plants in order to produce desired characteristics. As an Art, it depends on the intuition and past experiences of each individual breeder. As a Science, it depends on the theoretical and practical knowledge in the field of genetics, statistics, agronomy, plant pathology, and many others. As a Technology, plant breeding generates a useful product such as improved variety, hybrids, synthetics and composites.

The changes made in plants through plant breeding therefore must necessarily be permanent and heritable. Plant breeding generally depends on variability and yam breeding is no exception.

\section{Historical Aspects of Yam Breeding in Ghana}

The yam breeding efforts in Ghana is basically limited to few research institutes specifically Council for Scientific and Industrial Research-Crops Research Institute (CSIR-CRI) and CSIR-Savannah Agricultural Research Institute (CSIR-SARI). The former is mandated to research and develop yams within the Forest-Savannah Transition (area of highest yam production in Ghana) and Coastal Savannah Agroecology (limited but has unique varieties such as $D$. cayenensis cv Maale, D. rotundata cv Brass among others), and the latter same mandate in the Guinea Savannah Agroecology.

The curative function of yam is assigned to the CSIR-Plant Genetic Resource Research Institute (PGRRI) even though both CSIR-CRI and CSIR-SARI has a mandate for working collection. CSIR-CRI is so far the only institution in the country to have release new yam varieties (Otoo et al., 2005). 
Yam breeding in Ghana has progressed slowly over the years and has been championed by CSIR-CRI in collaboration with institution such as CSIR-Food Research Institute (CSIR-FRI), Ministry of Food and Agriculture (MOFA) (Table 1).

Table 1. List of local and international collaborating institutions

\begin{tabular}{|c|c|}
\hline International & Local \\
\hline $\begin{array}{l}\text { - International Institute of Tropical Agriculture (IITA) } \\
\text { - West and Central Africa Council for Agricultural } \\
\text { Research and Development (WECARD). }\end{array}$ & $\begin{array}{l}\text { - } \quad \text { Kwame Nkrumah University of Science and Technology } \\
\text { - } \quad \text { Farmers and Extension Agents of Ministry of Food and Agriculture } \\
\text { (MOFA), Wenchi, Effutu-Awutu-Senya and Ejisu Directorate } \\
\text { - } \quad \text { Farmers (Ejisu-Juaben, Effutu-Awutu-Senya and Wenchi Districts) } \\
\text { - } \quad \text { Root and Tuber Improvement Program (RTIP) }\end{array}$ \\
\hline
\end{tabular}

Up to 1998 , breeding efforts in Ghana was limited to germplasm collection and not much characterization was done. The collected germplasm were poorly curated resulting in admixtures and loss of germplasm. This period witnessed little or no funding for yam research in general and yam breeding in particular. It was therefore characterized with frequent need for germplasm collection whenever new donor-funded projects come into being.

The period 1999 to 2008 witnessed the upsurge in yam research activities especially under the Root and Tuber Improvement Programme (RTIP) and the subsequent release of three of new yam varieties (CRI Pona, CRI Kukrupa and Mankrong Pona ) in 2005 (Table 2). Yet again low funding for research and low multiplication ratios of yams resulted in slow and low dissemination of these varieties.

Table 2. Historical perspective of yam breeding in Ghana

\begin{tabular}{|c|c|c|c|}
\hline Parameter & Past (up to 1998) & Present (1999-2008) & Way Forward (2009 to Date) \\
\hline Structure & Part of Root and Tuber & Part of Root and Tuber & Autonomous \\
\hline \multirow[t]{3}{*}{ Objective(s) } & Yield & Yield & Industrial Products \\
\hline & & Pest and Disease Tolerance & Pest and Disease Tolerance \\
\hline & & Staking & Staking \\
\hline \multicolumn{4}{|l|}{ Size } \\
\hline Scientist & 1 (Agronomist) & Breeder & Breeders Including Hobbyist \\
\hline Technician & 1 & 2 & 6 \\
\hline Labour & 2 & 8 & 8 \\
\hline \multirow[t]{5}{*}{ Approach } & Pandisciplinary & Multidisciplinary & Multidisciplinary \\
\hline & 1-2 Outstations & Multiinstitutional & Multiinstitutional \\
\hline & & Transdisciplinary & \\
\hline & & Pandisciplinary & \\
\hline & & Across Yam Agroecology & Across Yam Agroecology \\
\hline \multirow[t]{3}{*}{ Source of Funding } & No Guarantee & Donor & Donor \\
\hline & & GOG & Private \\
\hline & & & GOG \\
\hline Type of Collection & Local Landrace & Local Landrace and Improved & \\
\hline Frequency of Collection & Sporadic & & \\
\hline \multirow[t]{2}{*}{ Germplasm Conservation } & in vivo & in vitro and in vivo & in vitro and in vivo \\
\hline & & & Cryopreservation \\
\hline \multirow[t]{2}{*}{ Source of Variation } & Natural Diversity & Natural Diversity & Natural Diversity \\
\hline & & Hybridization & Hybridization \\
\hline \multirow[t]{4}{*}{ Output } & No Significant Improvement & First-Ever Release of New Varieties & Targeted \\
\hline & $8 \mathrm{t} / \mathrm{ha}$ & Mankrong Pona & \\
\hline & & CRI Pona & \\
\hline & & CRI Kukrupa & \\
\hline
\end{tabular}


In recent times, workers on yam breeding have increased significantly, and there are numerous NGOs and private individuals working on yams to promote its dissemination in Ghana.

\section{Challenges Confronting the Yam Breeder}

\subsection{Increasing Human Population}

Yam is the second most important tuber crop in Africa, after cassava root, with production reaching just under one third the level of cassava (FAO, 1997). About 48.1 million tons of yam are produced annually in West Africa's "Yam Belt", which extends from Ivory Coast to Nigeria, representing over $90 \%$ of global production (FAO, 2011). It is produced on $4 \mathrm{M}$ ha annually in this sub-region and it is also an important source of income in West Africa. Yams play a very important part of the food security and livelihood systems of at least 60 million people in West Africa (Maroya et al., 2014). Yam is a primary agricultural commodity and cash crop in West Africa and Ghana is the second leading exporter of yams in the world. CSIR-CRI is a National Centre of Specialization being upgraded to Regional Centre of Excellence for Root and Tuber Research with a mandate to generate technologies fo the West African Sub-region (WAAPP, 2009). The main problem for breeding in general is that the population is growing faster than increases in food productivity, to reduce the use of harmful agrochemicals and to produce nutritious and healthful food is greater today. For a yam breeding programme in Ghana, with a mandate to serve the West Africa sub-region, the challenge is to generate improved yam varieties with good culinary characteristics acceptable consumers (both domestic and industrial) in the sub-region. Yams have been proven to be income and demand elastic (Otoo, 2001).

\subsection{Dwindling Arable Land}

The total arable land for agriculture in Ghana is decreasing due to urbanization and industrial development (Figure 1). There is therefore the urgent need for varieties with high productivity. Breeding therefore need to create varieties with high and stable yielding potential to be augmented with good agricultural practices.

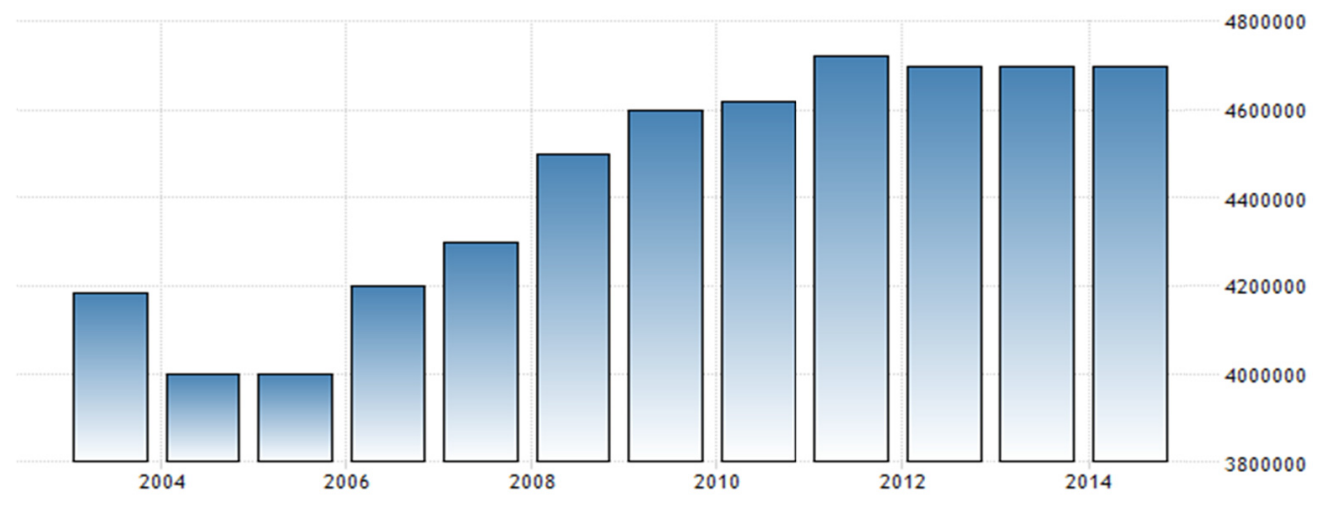

Figure 1. Avaliable arable land in Ghana

\subsection{Climatic Changes}

It is reported that in the Guinea Savannah and Forest-savannah agroecologies climate change $t$ climate change results in the reduction of grain yield by $19-41 \%$ and biomass declines by $11-33 \%$ across both agro-ecological zones (Macarthy et al., 2013). Rainfall is recent times is erratic, unpredictable and unevenly distributed. Yam is a seasonal crop and depends on natural rainfall for its production. In Ghana, there is a very low irrigation culture. Most yams are planted in November-February to meet the main season rains in March-June. With the changing rainfall volume and pattern ideal planting period is becoming increasingly difficult to predict. There is therefore an urgent need to develop drought/flood tolerant varieties.

\subsection{Mechanization}

Traditional yam cultivation is labour-intensive. More and more youth are avoiding such vocations. The existing farmers are aging and cannot sustain yam cultivation. The need therefore to develop varieties that respond better to chemical fertilizers, manures, irrigation and other improved systems of cultivation can not be over-emphasized. 


\section{Objectives of Yam Plant Breeding}

The basic aim of any yam improvement programme is to improve agronomical and economically useful characters in the crop. Specifically, the objectives of most programmes are geared towards:

\subsection{Higher Productivity}

High and stable yield has been the ultimate aim of most yam breeders. This can be achieved by developing more efficient genotypes having greater physiological efficiency. Differences exist among species with respect to yield potential.Dioscorea alata species are generally known to give far greater yields than $D$. rotundata species. $D$. rotundata species (late maturing type) also gives comparable yields to D. cayenensis (a late maturing species). Released varieties such as Mankrong Pona, CRI Pona and CRI Kukrupa are yielding twice as much as local landraces. With the increasing population coupled with dwindling arable land, the need to develop varieties with high productivity will continually be important.

\subsection{Improved Quality}

Yam tuber quality is assessed on the basis of texture (mealiness), taste (sweet, bland or bitter), aroma (sweet or non-aromatic) and after-taste (sweet, bland or bitter), with score on a scale of $1-5$, where $1=$ low and $5=$ high. Once these parameters are right, yams becomes almost suitable for all food forms and industrial use (Otoo, 2009).

\subsection{Disease and Insect Resistance}

Resistance varieties offer the cheapest and most convenient method of disease and insect management. Numerous pest and disease are important for yam breeding. Amongst the important pests of yams are nematodes (Scutelonemabradys, Meloidogyne and Pratylenchus). Insects such as leaf beetles, tuber beetle, scale insects, mealybugs have significant effect on the crop hence their control in the form of breeding is highly significant.

Viruses such as mosaic and shoe-string in addition to anthracnose, mostly D. alata, leaf spots, leaf blights and tuber rots are the important diseases that breeding is targeting. D. alata species generally are more susceptible to anthracnose disease. Promising genotypes that are tolerant to anthracnose are being evaluated for release in Ghana.

These parameters are also assessed based on both incidence (ratio) and severity on a scale of 1-5, where 1=low and 5=high (Orkwor et al., 1998).

\subsection{Short Duration Varieties}

Yam is a multispecies and has a wide range of maturity period. D. rotundata varieties matures during) 4-12 months; D. alata 10-12 months and D. cayenensis 10-12 months after emergence. Yam varieties such as $D$. rotundata cv Pona, $D$. rotundata cv Laribako are economically matured at 6 months after planting. They are therefore referred to as early maturing varieties. Very early maturing varieties such as D. rotundata cv Kulunku matures even faster (4 months after planting) are becoming very important. Yam breeding efforts must therefore target such early maturing varieties that may allow double cropping dormancy permitting.

\subsection{Non-Staked Varieties}

Yam is basically a climber. In the forest transition where there are few trees, farmers practice the parkland farming system where selected trees are left for the yam plant to climb on to receive better irradiation and increase yields. In the Guinea Savannah agroecology shorter stakes are adopted or the plant left unstaked. Modifying agronomic characteristics such as plant height will eliminate the need for stakes.

\subsection{Increasing Shelf-Life}

Elite yam varieties such as $D$. rotundata cv Pona and D. rotundata cv Laribako are known to have short shelf life. Developing early maturing varieties with thick tuber skin will aid in prolonging the shelf-life of these varieties.

\subsection{Dormancy}

Dormancy plays both beneficial and harmful role depending on the objective of the farmer. For a farmer wanting to double crop yam, the need for the harvested tuber to sprout immediately is paramount. Dormancy can be a nuisance when wanting to store the tuber for marketing. It is essential for yam breeders to manipulate the crop to suit our present needs.

\subsection{Adaptation to Abiotic Stresses}

Tolerance to drought/flooding and suitability to prevailing cropping systems (plant architecture, vigour and maturity period) are some of the abiotic stresses of importance in yam breeding. Improved genotypes such as 
TDr (95/19177) has being noted for its tolerance to drought conditions as well as its adaptability to no staking. Local varieties such as Dioscorea rotundata cv Afebetua has also being reported to have such qualities.

\section{Activities in Yam Breeding}

Yam breeding activities can be illustrated as follows:

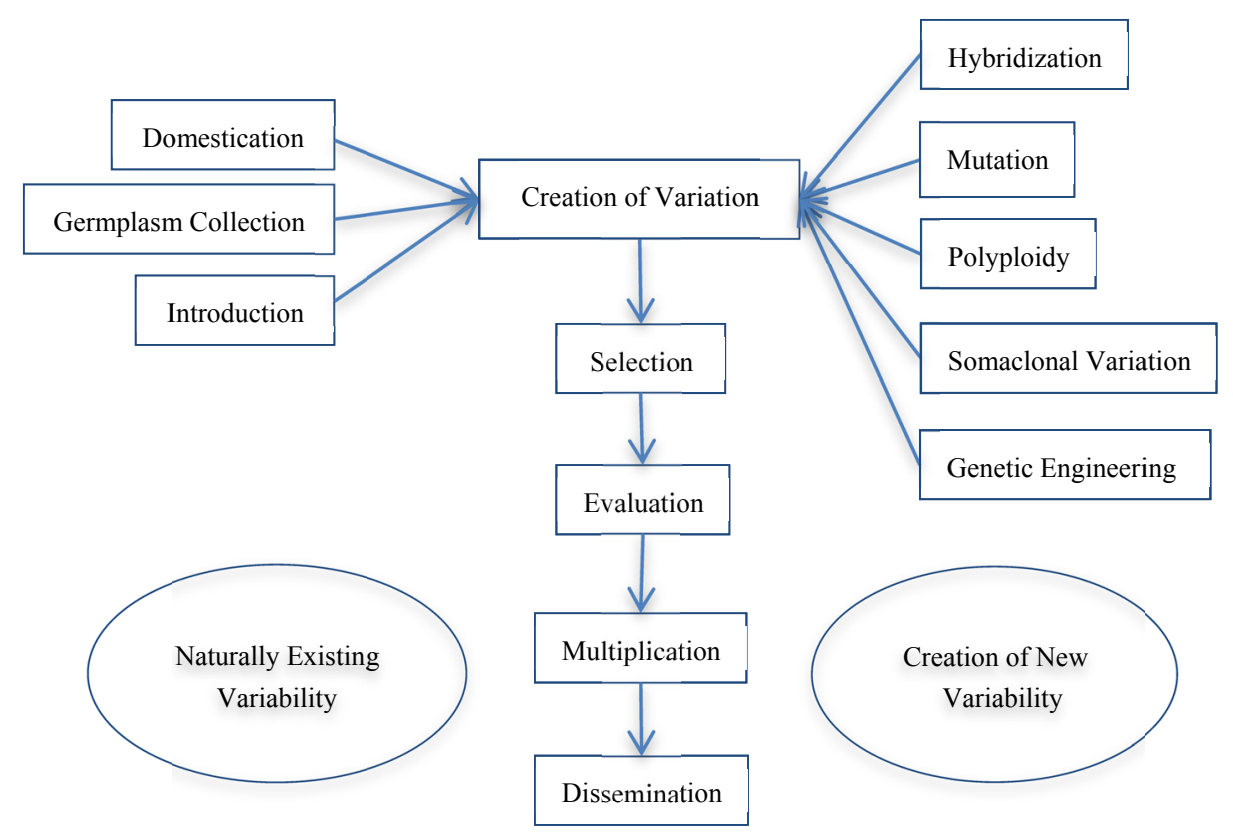

Figure 1. Graphical illustration of activities involve in yam breeding

Note. Adapted from Nagsar (2015).

\subsection{Creation of Variation}

Variability is the bedrock of crop improvement and it means the differences among the individuals of a population or species for a specific character. Variation is the source from which plant breeders are able to produce new and important cultivars. Alleles of varying forms at given loci in a population can be selected and fixed within a new individual or line

Genetic variations are heritable and are transmitted from one generation to other. Such variation is useful in selection. Success of any breeding programme usually depends on the desired genetic variation. Exploiting either the existing natural variability or creating new variability can lead to release of a new variety of yam. Domestication, germplasm collection and introduction are means of exploiting the naturally existing variability. New variability can also be created through hybridization, polyploidy, mutation, somaclonal variation and genetic engineering.

\subsection{Exploiting Naturally Existing Variability}

\subsubsection{Domestication}

'Yams are also believed to have originated in the tropical areas of three separate continents: Africa (mainly West Africa for D. rotundata, D. cayenensis and D. dumetorum), Southeast Asia (for D. alata and D. esculenta), and South America (for D. trifida). The Asiatic yam, D. alata, might have originated in tropical Burma and Thailand and D. trifida, the South American yam, is believed to date back to pre-Columbian times (Ayensu \& Coursey, 1972).

In West Africa, domestication of yam started as early as 50000 BC, during the Paleolithic era (Davies, 1967). However, archeologists believe that actual cultivation of yam started about $3000 \mathrm{BC}$, about the sametime when it started in Southeast Asia (Coursey, 1967; Davies, 1967; Alexander \& Coursey, 1969).

In Ghana, the important species are D. rotundata (white yam), D. alata (water yam), D. cayenensis (yellow 
Guinea yam), and D. dumentorium (bitter yam). The wild types present are D. abyssinica and D. preahensilis (kokoasebayere).

Wild yam types are domesticated through a process known as 'tuber ennoblement'. This refers to the process of transformation of the wild-type tuber (generally long, thin and more or less thorny) into a cultivated shape, which is shorter and larger in diameter (Coursey, 1967). Wild yams are sexually propagated while cultivated yams are vegetative propagated; however, farmers carry out intense vegetative propagation of the plants collected from forest areas (which could be wild or interspecific hybrids) for long periods of time, contributing to the domestication of species (Bhattacharjee et al., 2011).

There are three main methods for achieving this after collection of the wild types, are (i) Planting of the head region, (ii) introduction of an obstacle under the tuber to limit the extent of penetration of the tuber into the soil and (iii) "milking" that is double harvesting of the planted wild type.

D. rotundata cultivars, the white Guinea yams believed to have been domesticated from D. praehensilis in degraded forest zones or savannah agroecology. D. cayenensis, known as the yellow Guinea yam, is mainly grown in humid forest areas and is believed to be a product of an interspecific hybrid between D. burkilliana Miège and D. praehensilis or D. abyssinica (Terauchi et al., 1992; Ramser et al., 1997). Other workers are suggesting $D$. burkillianaor, $D$. minutijlora as ancestors of $D$. cayenensis. In the savanna zone, the wild species involved in the process of domestication belong to either D. abyssinica Hochst ex Kunth or to D. praehensilis Benth.

Domestication of wild yam is still an active process. The domestication process mainly leads to early maturing cultivars, which are produced in double-harvest systems. The practice of domestication is however decreasing, especially in the regions where commercial yam production is well developed (Venier et al., 2001).

Water yam is sexually sterile and is conventionally cultivated by clone propagation with tubers (Coursey, 1967).

\subsubsection{Germplasm Collection}

Collection of germplasm within and without the country has also been a major source of variability in the breeding collection of the country. For instance, in the development of the three release varieties (CRI Pona, Mankrong Pona and CRI Kukrupa) germplasm was obtained from IITA and PGRRI (Table 3).

Table 3. Sources and quantities of genotypes used in yam improvement programme in 2000

\begin{tabular}{lll}
\hline Institution & Material Type & Number of Genotypes \\
\hline Old Crops Research Institute & Local landraces (54) \& Exotic (4) & 8 \\
New CRI Collections & Open-pollinated (18) \& local landraces (12) & 30 \\
Plant Genetic Resource Research Institute & Local landraces & 30 \\
(PGRRI, then Plant Genetic Resource Center, PGRC) & & 153 \\
IITA \& Allied Sources & Exotic & \\
& Total & 278 \\
\hline
\end{tabular}

\subsubsection{Introductions}

Introductions have also being a major means of creating variability in the breeding programs in Ghana. IITA has been a curator for yam germplasm in the sub-region. Germplasm transfer/exchanges between countries have been facilitated by IITA, which acts as a clearinghouse where materials are cleaned and transferred across the sub-region as indicated in Table 1.

Introduction of $D$. alata is a case in point, where Florido was introduced into the country and shared amongst farmer using the "match box" as the standard sett size. This resulted in reference to D. alata as "matches" even in present day. It was further introduced into the villages of the Guinea Savannah by one farmer Seidu hence the reference to $D$. alata (matches) as "Seiduble" after the farmer Seidu who first introduced the yam to the farmers.

New germplasm generated from hybridization and other sources are also freely shared among partner research institutions within the sub-region. This process is still in progress and has led to the spread of important varieties across the sub-region. 


\subsection{Exploiting Newly Created Variability}

\subsubsection{Hybridization}

Stebbins (1958) defined hybridization as the "crossing between individuals belonging to separate populations which possess different adaptive norms".

The major limiting factors for this approach to crop improvement have been identified as sparse flowering, poor synchronization of male and female flowering phases and lack of efficient pollination mechanisms (Abraham et al., 1989).

D. abyssinica and and D. praehensilis, have good resistance to viruses whilst D. nummularia and D. transversa, may possess resistant genes for anthracnose disease. The importance of these diseases necessitates the crossing of this wild species to the closely related relatives of $D$. rotundata and $D$. alata, which are susceptible to viruses and anthracnose respectively.

Cross-compatibility and poor synchronization of flowering among other factors are militating against inter-specific hybridization of these species. Crossing D. rotundata to D. cayenensis is possible however crossing either $D$. rotundata or $D$. cayenensis has not been possible (IITA unpublished data).

It must be noted that $D$. cayenensis often flower male. D. dumentorum flower both male and female and exhibit monoeicy. Similarly $D$. alata exhibit monoeicy. D. rotundata exhibit both monoeicy and dioecy. D. rotundata cv Pona and D. rotundata cv laribako all flower mostly male, however CRI Pona is a female and there are rare cases of having male and female on the same plant. D. rotundata cv Serwa and D. rotundata cv Chenchito are all females. D. rotundata cv Dente exhibit monoiecy, having both male and female on the same plant and dioecy.

\subsubsection{Mating Designs}

It refers to a system of crossing, which is used to develop progenies of certain kind that serve to predict the genetic worthiness of their parents. In yam breeding, both incomplete (open-pollinated or pollen-mix; only one parent is known) and complete pedigree (both parents known) designs are useful.

Often the objective informing the choice of mating design in yams are:

1) Progeny testing;

2) Estimation of variance components;

3) Determination of General combining ability (GCA) and specific combining ability (SCA);

4) Creation of base population;

5) Determination of narrow sense heritability, and;

6) Estimation of genetic gains.

The Incomplete pedigree design, has the following pros:

1) GCA can be estimated;

2) Helps in rogueing of genetically inferior plants;

3) Advanced generation selection can be made;

4) Provides estimates of additive gene variances and heritability values;

5) Easiest and least expensive;

6) Used to quickly test selected plants.

The following are some weaknesses of this design:

1) SCA cant be estimated;

2) Limited utility for future generation;

3) Possibility of selfing;

4) Inbreeding depression;

5) Lack of complete pedigree.

In the complete pedigree design often the factorial approach known also as North Carolina II (Tester $\times$ Line Design) where selected males are all crossed with selected females are the most preferred.

This has the following advantages: 
1) Very useful in progeny testing programme;

2) Allows a reasonable estimation of variance components and heritabilities;

3) GCA and SCA can be estimated;

4) Additive and non additive variances.

It has also has 2 main limitations:

1) The number of parents that can be selected for the subsequent generation will be limited to the number of testers.

2) Small number of unrelated families can be generated.

\subsubsection{Polyplody Breeding}

Polyploid cells and organisms are those containing more than two paired (homologous) sets of chromosomes. Most species with cells have nuclei (Eukaryotes) are diploid, meaning they have two sets of chromosomes — one set inherited from each parent.

Polyploidy is the heritable condition of possessing more than two complete sets of chromosomes. Most polyploids have an even number of sets of chromosomes, with four being the most common (tetraploidy).

Polyploidy breeding refers to induced chromosome manipulation. Success is wholly dependent on the control of chromosome pairing and recombination in polyploids and their hybrid derivatives. Breeding strategies for transferring genes across ploidy levels depend on their origin.

Polyploidy provides the opportunity for selection to sculpt a variety of new gene functions, traits, and lineages.

Polyploidy seems to be favored in long lived/perennial plants possessing various vegetative means of propagation (e.g. Yam, Artemisiaetc.) and in those with frequent occurrences of natural inter-specific hybridizations (Hilu, 1993).

Breeding strategies for transferring genes across ploidy levels depend on their origin.

Types of Polyploidy:

1) Autopolyploidy
a) Autotriploidy $(3 \times)$
b) Autotetraploidy $(4 \times)$
c) Autopentaploidy $(5 \times)$
d) Autohexaploidy (6×)

\section{2) Allopolyploidy}

a) Allotetraploidy $(2 \times 1+2 \times 2)$

b) Allohexaploidy $(2 \times 1+2 \times 2+2 \times 3)$

c) Allooctaploidy $(2 \times 1+2 \times 2+2 \times 3+2 \times 4)$

The cultivated yam species $D$. rotundata $(2 \mathrm{n}=40)$ has been considered as a tetraploid species with a basic chromosome number of ten (Scarcelli et al., 2005), D. abyssinica and D. praehensilis are considered by Hamon et al. (1997) and Terauchi et al. (1992) as wild relatives of $D$. rotundata. These two species have been assumed to be tetraploid, with $2 \mathrm{n}=40$ chromosomes (Miege, 1952).

D. alata is also known to exhibit different levels of ploidy, including diploid $(2 \times=40)$, triploid $(3 \times=60)$, and tetraploid $(4 \times=80)$ forms within the species (Abraham \& Nair, 1991; Gamiette et al., 1999; Egesi et al., 2002; Arnau et al., 2009; Babil et al., 2010; Obidiegwu et al., 2010). Babil et al. (2010) reported that three levels of ploidy, diploid, triploid, and tetraploid, were identified in a landrace collection of water yam from Myanmar. They disclosed that the ploidy variations considerably affected the intra-specific diversity of leaf and stoma phenotypes.

\subsubsection{Mutation}

Mutation has been defined as a spontaneous heritable change in plants. It was always considered as "a-shot-in-the-dark" since its effect is highly unpredictable and the target unknown. This can be induced by chemical or radiations means.

Recent advances in genomics technology have led to a radiation of genomic techniques into applied breeding in general and mutational breeding specifically. Technologies such as high throughput sequencing has allowed for 
the relatively cheap and fast genome sequencing of plants. Methods such as TILLING (Targeting Induced Local Lesions in Genomes), Zinc finger nuclease mediated mutagenesis, and the use of meganucleases, has allowed us to produce targeted mutations in crop plants to delineate gene function as well as improve cultivars. These new and more specific methods are very promising.

When attempting to effect mutation in Yam (vegetatively propagated species) it is important to note the chimeric nature of mutagenic treatment. All cells exposed to the mutagen will not necessarily incur mutations, but those that do incur mutations, will give rise to cells exhibiting the mutation. For this reason it is important to treat parts of the plant that will give rise to either seed or vegetative propagules. Identification and propagation of the necessarily large numbers of plants to identify successful mutants is difficult for many vegetatively propagated plants, however, once one is identified, the mutation is fixed in the cloned progeny.

Yams can also be breed mutationally using in vitro techniques. This can be used to mutate plant material, and allows for the regeneration of large numbers of plantlets. This system is highly amenable to both vegetative and seed propagated species.

For true botanical seeds treatment with mutagenic agents will give rise to chimeric plants. Chimeric plants produce both mutant and non-mutant seed. This can be problematic; however, one just needs to plant more seeds to find the desired mutants. As long as an efficient screening method is in place, this should produce no significant pitfalls. Mutagenic treatment of seed is by far the most popular method in mutation breeding programs.

It is worth noting that mutagenesis of polyploid plant species is difficult. Because most mutations are recessive, plants must be homozygous to display the trait. Polyploid conditions can further complicate the process of reaching homozygosity for the mutation, so must be selfed for additional generations to ensure presence of the mutation.

\subsubsection{Somaclonal Variation}

It is defined as genetic variation observed among progeny of plants regenerated from somatic cells culturedin vitro. It is therefore a general phenomenon in tissue culture-regenerated plants of many species. Several typical abnormal phenotypes have been detected in tissue culture-propagated date palms. Variation from the source phenotypes is undesirable in the commercial propagation of specific cultivars, and efforts have been made to eliminate the formation of these off-types.

In yams, somaclonal variations in pigmentation occurred repeatedly during the clone propagation of the landrace 'Okinawa A' of water yam, Dioscorea alata L. The recurring somaclonal variations are considered to affect the genetic diversity within the species and to provide useful genetic resources for improvement of water yam (Babil et al., 2012).

\subsubsection{Genetic Engineering}

Insert Marian's contribution.

\section{The Yam Breeding Scheme}

The yam-breedingprogramme goes through a series of steps all geared towards the achievement of a specific objective. This series of steps is known as a breeding scheme (Figure 2). The significant steps within the breeding scheme are clonal collection, hybridization blocks, seedling nursery, clonal evaluation, Preliminary Yield Trial (PYT), Advanced Yield Trail (AYT), multiplication, and release and registration as variety. Each step after clonal collection is preceded by an evaluation and selection step.

The adoption of participatory breeding approaches and effective and efficient statistical methods such as Augmented designs coupled with effective strategy of concurrently multiplying promising varieties (at AYT) have drastically reduced the time for generation of new or improved variety from 10-12 years to 6-7 years. 


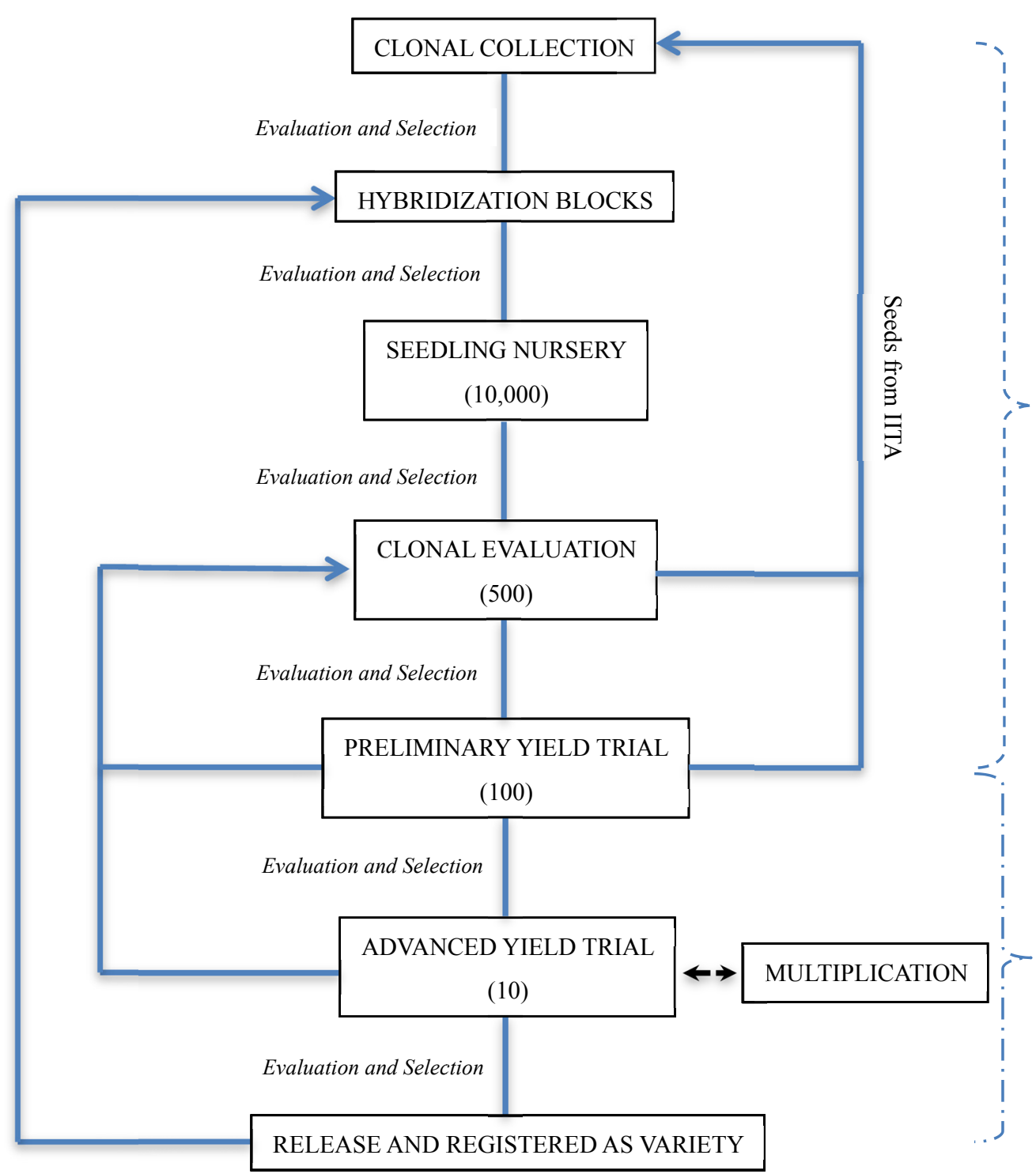

Figure 2. Yam improvement scheme in Ghana (approximate number of clones in parenthesis). - - - - - On-station trials and -...... On-farm trials. The whole breeding progamme is participatory in nature hence stakeholders are involved at all stages

\subsection{Clonal Collection}

Based on previous work, materials with good potential were produced and to significantly contribute to the breeding objectives and also collected flower to constitute the clonal collection. For instance, previous has shown the following materials with good potential for a given character and could serve as potential parents (Table 4). 
Table 4. Sex and Characteristics of some selected yam genotypes/varieties

\begin{tabular}{lll}
\hline \multirow{2}{*}{ Genotype/Variety } & \multicolumn{2}{c}{ Characteristics } \\
\cline { 2 - 3 } & Potential & Predominant Sex \\
\hline Pona & Tuber quality & Male \\
CRI Pona & Tuber quality and shelf life & Female \\
TDr 95/19177 & Non-staking; drought tolerant & Female \\
Dente & Storability; tuber quality & Female \\
CRI Kukrupa & Multiple tubering & Female \\
Mankrong Pona & Tuber quality; storability & Female \\
Chenchito & Tuber quality, Profuse flowering & Female \\
\hline
\end{tabular}

At the clonal collection stage, introductions from farmer fields and IITA are incorporated into the collections. These materials will be evaluated to confirm the characteristic of interest and planted in hybridization blocks with relevant parents in a particular mating design. North Carolina II has been the design of preference in generating our biparentalmatings.

Complete pedigree approaches are used to generate botanic seeds from biparental crosses and incomplete pedigree approach to generate botanic seeds from open pollinated fields planted in isolation from the main plot.

During selection, the individual plant or group of plants having the desired characters are picked up from a population eliminating the undesirable ones. Those selected plants are are looking promising for the character on the basis of phenotype. The selected plants are then allowed to grow for setting their seeds. Seeds are selected and again a new crop is developed.

This process is repeated again and again till the desired result is achieved. Selection acts on the genetic variation present in a population and produces a new population with improved characters.

\subsection{Seedling Nursery}

The true botanical seeds obtained through either open pollinated or controlled hybridization needs to be assessed at seedling nursery due to the tender nature of the seed. The true botanical seed of yams are winged capsule. Evaluation and selection is based on pest and disease assessment to exert a selection pressure of $95 \%$. The selected clones are advanced to the clonal evaluation stage. The unselected clones are discarded. This evaluation is conducted at on-station.

At the nursery stage, the testline is usually a single seed planted in a screenhouse and evaluated for pest and diseases. Observation is also made on yield potential even though that is not the main focus at this stage.

The newly selected lines/strains/populations are further tested for yield and other traits and their performance comparing with existing best varieties called Checks at the PYT and AYT.

At the PYT, a selection pressure of $80 \%$ is applied. If the new lines/strain/population shows superior performance to the checks, further selected and evaluated at $90 \%$ selection pressure at the AYT stage. Success for any of the new lines/genotypes will lead to its being proposed for release as a variety.

\subsection{On-Station}

The CSIR-CRI has six on-station sites for yam improvement, namely Fumesua (Forest agroecology), Ejura, Kintampo, Wenchi and Atebubu (Forest-Savannh Transition) and Bodwease (Coastal Savannah agroecology). The clonal collection is normally assembled at the main on-station facility at Fumesua. Similarly, the Clonal Evaluation and Seedling Nursery are established on-station. The on-station trials are full researcher-managed.

The National Variety Release Committee expects a mandatory two (2) year on-station evaluation and two (2) on-farm evaluations before a variety can be accepted for released.

\subsection{On-Farm}

Ejura, Kintampo, Wenchi and Atebubu (Forest-Savannh Transition) and Bodwease (Coastal Savannah agroecology) are the on-farm sites for evaluation by CSIR-CRI. Except for the Preliminary Yield Trial that is solely researcher-managed but with stakeholder participation, all other trials are farmer-managed with researcher participation.

At this stage Augmented RCB designs are adopted to facilitate evaluation of high numbers of promising genotypes available at PYT and AYT. 


\section{Multiplication}

This step concerns with large scale certified seed production of the released and notified variety.

There are quite a number of options available for multiplication of newly released varieties. The multiplication ratio (MR) is the major determinate in the choice of the method of propagation.

$\begin{array}{ll}\text { Milking } & 1: 4-6 \\ \text { Tissue Culture } & 1: 200 \\ \text { Minisett } & 1: 40 \\ \text { Vine techniques } & 1: 240 \\ \text { Hydroponics } & 1:>1000 \\ \text { Aeroponics } & 1:>1000 \\ \text { Bioreactor } & 1:>1000\end{array}$

\section{Distribution}

The seed must goes through 3 stages: Breeder Seed, Foundation Seed and Certified seed stages. Certified seed is ultimately sold to the farmers who use it for commercial crop cultivation. There are procedures and steps that seed of a variety must through before reaching the commercial entity to obtain and plant. These procedures and steps are known as the seed sytems. There are three main systems, namely formal, informal and semi-formal systems.

Formal: The formal seed sector is an official or private control of seed monitored through the entire process of breeding, multiplication, processing and storage, leading to the final product.

$>\quad$ The informal seed sector is simply the farmers themselves that provide each other and themselves with seed for sowing. This seed may be cleaned manually, but is otherwise untreated and thus a potential carrier of various diseases.

$>$ Semi-Formal refers to the generation of Quality Declared Seeds.

\subsection{Formal System}

The formal systems have uniform standards based on Distinctness, Uniformity and Stability (DUS) and Value for Cultivation and Use (VCU).

The following models could be adopted depending on the ease of generation of planting materials:

Model 1: 3-generational model: breeder $\rightarrow$ foundation $\rightarrow$ certified

Model 2: 4-generational model: breeder $\rightarrow$ foundation (I) $\rightarrow$ foundation (II) $\rightarrow$ certified

Model 3: 4-generational model: breeder (I) $\rightarrow$ breeder (II) $\rightarrow$ foundation (II) $\rightarrow$ certified

Model 4: 5-generational model: breeder $\rightarrow$ foundation (I) $\rightarrow$ foundation (II) $\rightarrow$ certified (I) $\rightarrow$ certified (II)

Generally, due the low multiplication ratio of yams, a 4-generational model is more appropriate, than 3. If multiplication ratio $(\mathrm{MR})$ is low $(\mathrm{MR}=1:<200)$ such as milking and minisetting, then either Model 2 or 3 must be used. For multiplication systems with high multiplication ratio such as vine multiplication technique, tissue culture, hydroponics and aeroponics ( $M R=1:>200)$ a 3-generational model such as Model 1 is appropriate.

In instances of adopting Model 3 where VMT is being used for multiplication, season 1 can generate microtubers which will be planted in season II and "enhanced milking technique" adopted to generate seed yams at (Breeder II) for subsequent transfer to foundation seed developer.

Presently in Ghana, under the Yam Improvement for Income and Food Security in West Africa (YIIFSWA) programme Model 1 is being used.

\subsection{Informal System}

This system provides a dynamic and flexible system of seed supply, usage, handling, trade and exchange. It has the limitation of allowing the continuous use of untested seed, which inevitably leads to a degeneration of the seed quality (genetically, physiologically and seed health wise).

Improving this system of planting material by positive selection and renewing their tuber seed every 3-5 years will greatly improve 


\subsection{Semi-Formal $=$ Quality Declared Seeds}

This refers to a seed system in which a proposed 10 per cent of the seed produced and distributed is checked by an autonomous seed control agency and the rest by the seed producing organization. This is often used in instances where a local landrace of a good quality is being multiplied for dissemination.

The objectives are often to:

$>$ Guide the production of clean, disease- free planting material of vegetatively reproduced crops.

$>$ Raise the physiological and phytosanitary quality of the plant reproductive materials available to smallholders, and as a consequence, to increase agricultural production and productivity.

$>$ Generate seeds primarily by seed producers at community level or field extension workers.

$>$ Designed and allow easy monitoring and verification of the production and distribution process.

It must however be compatibility with National Seed Regulations of the land.

\section{Multiplication Methods}

When seed tubers are scarce, rapid multiplication techniques through positive selection can be used to meet planting needs.

$>$ Traditional methods

- $\quad$ Milking

- Junking

- Use of bulbils

$>$ Improved methods

- Tissue culture

- Minisett

- Vine

\section{Conclusions}

The yam-breeding programme in Ghana has many actors from formal and informal systems. It has adopted a system of incorporating indigenous knowledge into a formal knowledge system and the informal into formal breeding systems. This has drastically reduced the number of years needed to develop a yam variety by 4-5 years. The first-ever release yam varieties were developed by CSIR-CRI and many more varieties are being developed.

\section{References}

Abraham, K., Nair, S. G., \& Sreekumari, M. T. (1989). White yam, Dioscorea rotundata Poir., dwarf type. Tropical Agriculture (Trinidad), 66(2), 184-186.

Abraham, K., \& Nair, P. G. (1991). Polyploidy and sterility in relation to sex in Dioscorea alata L. (Dioscore aceae). Genet., 83, 93-97. https://doi.org/10.1007/BF00058525

Adelusi, A. A., \& Lawanson, A. D. (1987). Disease induced changes in carotenoid content of edible yam (Dioscoreas pp.) infected by Botryodiplodia theobromae and Aspergillus niger. Mycopathologia, 98, 49-58. https://doi.org/10.1007/BF00431018

Alexander, J., \& Coursey, D. G. (1969). The origins of yam cultivation. In U. J. Peter \& G. W. Dimbleby (Eds.), The domestication and exploitation of plants and animals (pp. 405-425). Cerald Duckworth: London, UK.

Arnau, G., Nemorin, A., Maledon, E., \& Abraham, K. (2009). Revision of ploidy status of Dioscorea alata L. (Dioscore aceae) by cytogenetic and microsatellite segregation analysis. Theor. Appl. Genet., 118, 1239-1249. https://doi.org/10.1007/s00122-009-0977-6

Ayensu, E. S., \& Coursey, D. G. (1972). Guinea yams. The botany, ethnobotany.use and possible future of yams in West Africa. Econ Bot, 26(4), 301-318. https://doi.org/10.1007/BF02860700

Babil, P. K., Irie, K., Shiwachi, H., Ye, T. T., Toyohara, H., \& Fujimaki, H. (2010). Ploidy variation and their effects on leaf and stoma traits of water yam (Dioscorea alata L.) collected in Myanmar. Tropic. Agric. Dev., $54,132-139$.

Bhattacharjee, R., Lava Kumar, P., Gedil, M., Sartie, A., Dumet, D., Otoo, E., ... Asiedu, R. (2011). Yams (Dioscorea spps.). In C. Kole, (Ed.), Wild Crop Relatives: Genomic \& Breeding Resources (Vol. 8). 
Springer: Heidelberg, Berlin.

Coursey, D. G. (1967). Yams. An Account of the Nature, Origins, Cultivation and Utilisation of the Useful Members of the Dioscore aceae. Longmans, Green and Co Ltd., London.

Davies, O. (1967). West Africa before the Europeans. Methuen, London, UK.

Egesi, C. N., Pillay, M., Asiedu, R., \& Egnnjobi, J. K. (2002). Ploidy analysis in water yam, Dioscorea alata L. germplasrn. Euphytica, 128(2), 225-230. https://doi.org/10.1023/A:1020868218902

Food and Agriculture Organisation (FAO). (2005). Food \& Agricultural Organization. Production Year Book, 46(115), 18-24.

Gamiette, F., Bakry, F., \& Ano, G. (1999). Ploidy determination of some yam species (Discorea spp.) by how cytometry and conventional chromosomes counting. Genet Resour Crop Evol, 46, 19-27. https://doi.org/ 10.1023/A:1008649130567

Hamon, P., Dumont, E., Zoundjibekpon, J., Ahoussou, N., \& Toure, B. (1997). Les ignames. In A. Charrier, M. Jacquot, S. Hamon, \& O. Nicolas (Eds.), L'amelioration des plantestropicales (pp. 385-400). CIRADORSTOM Reperes, Paris, France.

Hilu, K. W. (1993). Polyploidy and the evolution of domesticated plants. Amer. J. Bot., 80, 1494-1499. https://doi.org/10.2307/2445679

MacCarthy, D. S., Adiku, S. G. K., \& Yangyuoru, M. (2013). Assessing the Potential Impact of Climate Change on Maize Production in Two Farming Zones of Ghana Using the CERES-Maize Model. Ghana Policy Journal Special Edition on Climate Change, 27-39.

Maroya, N., Asiedu, R., Lava Kumar, P., Mignouna, D., Lopez-Montes, A., Kleih, U., ... Otoo, E. (2014). Yam Improvement for Income and Food Security in West Africa: Effectiveness of a Multi-Disciplinary and Multi-Institutional Team-Work. Journal of Root Crops, 40(1), 85-92.

Obidiegwu, J., Rodriguez, E., Ene-Obong, E., Loureiro, J., Muoneke, C., Santos, C., ... Asiedu, R. (2010). Ploidy levels of Dioscorea alata L. germplasm determined by flow cytometry. Genet. Resour. Crop Evol., 57, 351-356. https://doi.org/10.1007/s10722-009-9473-8

Orkwor, G. C., Asiedu, R., \& Ekanayake, R. (1998). Genetic improvement. Food yams: Advances in research (pp. 63-104). FITNNRCRI, Nigeria.

Otoo, E., \& Asiedu, R. (2005). The First-Ever Formal Release of Yam Genotypes in Ghana. In J. S. Tenyiwa, E. Adipala, P. Nampala, G. Tusiime, P. Okori, \& W. Kyamuhangire (Eds.), Proceedings of the 7th African Crop Science Society Conference. Kampala, Uganda, December 5-9, 2005 (pp. 203-208).

Otoo, E. (2001). Yam Production in Ghana: A Food Security Enhancer or an Environmental Degrader. In M. Akoroda (Ed.), Proceedings of the 8th Symposium of the International Society for Tropical Root Crops-Africa Branch Triennial Workshop, Ibadan, Nigeria, November 12-16, 2001 (pp. 387-391).

Otoo, E., \& Asiedu, R. (2009). Sensory evaluation: The last hurdle in varietal development of yams (Dioscorea rotundata, Poir) in Ghana. Afr. J. Biotechnol., 8, 5747-54. https://doi.org/10.5897/AJB09.1053

Ramser, J., Weising, K., Lopez Peralta, C., Terhalle, W., Terauchi, R., \& Kahl, G. (1997). Molecular marker based taxonomy and phylogeny of Guinea yam (D. rotundata-D. cayenensis). Genome, 40(6), 903-915. https://doi.org/10.1139/g97-117

Scarcelli, N., Ogoubi, D., Clement, A., Tostain, S., \& Pham, J. L. (2005). Segregation patterns of isozyme loci and microsatillite markers show the diplody of African yam Discorea rotundada $(2 \mathrm{n}=40)$. Theor. Appl. Gene., 111, 226-232. https://doi.org/10.1007/s00122-005-2003-y

Stebbins, G. L. Jr. (1958). The inviability, sterility and weakenss of inter-specific hybrids. Adv. Genet., 9, 147-215. https://doi.org/10.1016/S0065-2660(08)60162-5

Terauchi, R., Chikaleke, V. A., Thottappilly, G., \& Hahn, S. K. (1992). Origin and phylogeny of Guinea yams as revealed by RFLP analysis of chloroplast DNA and nuclear ribosomal DNA. Theoretical and Applied Genetics, 83, 743-751. https://doi.org/10.1007/bf00226693

Vernier, P., \& Dansi, A. (2000). Participatory assessment and farmers' knowledge on yam varieties (D. rotundata) in Benin. In M. Nakatani \& K. Komaki (Eds.), Proceedings of the 12th Symposium of ISTRC, Tsukuba, Japan, ISTRC 2000-Potential of Root Crops for Food and Industrial Resources (pp. 360-365). 


\section{Copyrights}

Copyright for this article is retained by the author(s), with first publication rights granted to the journal.

This is an open-access article distributed under the terms and conditions of the Creative Commons Attribution license (http://creativecommons.org/licenses/by/4.0/). 